\title{
THE PERCEPTIONS OF WORKERS IN A LONG-TERM CARE INSTITUTION FOR OLDER ADULTS REGARDING THE FAMILY ${ }^{1}$
}

\author{
Naiana Oliveira dos Santos ${ }^{2}$, Margrid Beuter ${ }^{3}$,Nara Marilene Oliveira Girardon-Perlini', Lisiane Manganelli \\ Girardi Paskulin ${ }^{5}$, Marinês Tambara Leite ${ }^{6}$, Maria de Lourdes Denardin Budó ${ }^{7}$
}

\footnotetext{
${ }^{1}$ Article extracted from the dissertation - The family of the institutionalized older adult: perceptions of workers in a longterm care institution, presented to the Postgraduate Program in Nursing (PPGENF) of the Univeridade Federal de Santa Maria (UFSM), in 2013.

2 Doctoral student of the PPGENF, Universidade Federal do Rio Grande do Sul (UFRGS). Fellow of the CAPES. Porto Alegre, Rio Grande do Sul, Brazil. E-mail: naiaoliveira07@gmail.com

${ }^{3}$ Ph.D. in Nursing. Associate professor in the Department of Nursing and PPGENF, UFSM. Santa Maria, Rio Grande do Sul, Brazil. E-mail: margridbeuter@gmail.com

${ }^{4}$ Ph.D. in Nursing. Adjunct professor of the Department of Nursing, and of the PPGENF/UFSM. Santa Maria, Rio Grande do Sul, Brazil. E-mail: nara.girardon@gmail.com

${ }^{5}$ Ph.D. in Health Sciences. Adjunct professor of the Department of Vocational Assistance and Guidance and of the PPGENF/ UFRGS. Porto Alegre, Rio Grande do Sul, Brazil. E-mail: paskulin@orion.ufrgs.br

${ }^{6}$ Ph.D. in Biomedical Gerontology. Adjunct professor of the Department of Health Sciences, UFSM. Santa Maria, Rio Grande do Sul, Brazil. E-mail: tambaraleite@yahoo.com.br

${ }^{7}$ Ph.D. in Nursing. Associate professor of the Department of Nursing and PPGENF/UFSM. Santa Maria, Rio Grande do Sul, Brazil. E-mail: lourdesdenardin@gmail.com
}

\begin{abstract}
This study aimed to investigate the perception of the workers in a Long-Term Care Institution for the Elderly regarding the families of the older adults in the institution. It is qualitative research, undertaken with 16 workers of the multidisciplinary team. Data collection occurred in February-June 2012, through semi-structured interviews. The technique used for treatment of the data was thematic analysis. The results indicate that the family members visit the Long-Term Care Institution for the Elderly rarely, with commemorative dates being the main occasions in which they appear. The workers evidenced some situations of abandonment, in which the family does not visit the older adult even when called. They understand that nobody can substitute the role of the family, as it is the reference for the older adults. Therefore, spending time with the family can positively influence the well-being of the older adults in institutions.
\end{abstract}

DESCRIPTORS: Homes for the aged. Workers. Family. Aged.

\section{PERCEPÇÃO DE TRABALHADORES DE UMA INSTITUIÇÃO DE LONGA PERMANÊNCIA PARA IDOSOS ACERCA DA FAMÍLIA}

RESUMO: Este estudo objetivou conhecer a percepção dos trabalhadores de uma Instituição de Longa Permanência para Idosos sobre as famílias das idosas institucionalizadas. Trata-se de uma pesquisa qualitativa realizada com 16 trabalhadores da equipe multidisciplinar. A coleta dos dados ocorreu de fevereiro a junho de 2012, por meio da entrevista semiestruturada. A análise temática foi a técnica empregada para o tratamento dos dados. Os resultados apontam que os familiares vão pouco à uma Instituição de Longa Permanência para Idosos, sendo as datas comemorativas as principais ocasiões em que eles comparecem. Os trabalhadores evidenciaram algumas situações de abandono em que a família não visita a idosa, mesmo quando chamada. Compreendem que ninguém substitui o papel da família, pois ela é referência para as idosas. Portanto, conviver com a família pode influenciar positivamente no bem-estar das idosas institucionalizadas.

DESCRITORES: Instituição de longa permanência para idosos. Trabalhadores. Família. Idoso.

\section{PERCEPCIÓN DE LOS TRABAJADORES UNA INSTITUCIÓN DE LARGA PERMANENCIA PARA ANCIANOS ACERCA DE LA FAMILIA}

RESUMEN: Este estudio tuvo como objetivo conocer la percepción de los trabajadores una Institución de Larga Permanencia para Ancianos de la familia de los ancianos institucionalizados. Se trata de una investigación cualitativa tenido con 16 trabajadores la equipo multidisciplinario. Los datos fueron recolectados de febrero a junio de 2012, por medio de la entrevista semiestructurada. La análisis temático fue la técnica utilizada para el procesamiento de datos. Los resultados muestran que la familia vai poco em Institución de Larga Permanencia para Ancianos, siendo las fechas conmemorativas las principales ocasiones en las que asisten. Los trabajadores presentaron algunas situaciones de abandono en que la familia no visitar a los ancianos, aun cuando se le llama. Comprender que nadie reemplaza el papel de la familia, ya que es una referencia a los ancianos. Por lo tanto, convivir con la familia puede influir positivamente en el bienestar del ancianos institucionalizados.

DESCRIPTORES: Hogares para ancianos. Trabajadores. Familia. Anciano. 


\section{INTRODUCTION}

Significant changes have been observed in the demographic and health patterns of the world's population, resulting in a considerable increase in the elderly population. ${ }^{1}$ The change in the age structure, the greater participation of women in the job market, and new family arrangements are socio-demographic conditions which reduce the availability of domestic caregivers. ${ }^{2-3}$

The reduced alternatives which the families have, for them to be with their elderly relatives in the home space, in conjunction with the condition of older adults without a family reference, have promoted an increase in demand for Long-Term Care Institutions for the Elderly (LTCIs). ${ }^{4}$ This context, and the absence of availability of family resources for the care of the older adult, lead the older adult to live alone or in a LTCI. Thus, the increase in the elderly population, with reduced physical and cognitive capacity, requires the LTCIs to provide social support and healthcare actions. In the light of this demand, the LTCIs - previously symbols of disadvantage and abandonment - are being transformed into options for residence for older adults with different economic conditions. ${ }^{5}$

Regarding this panorama, the demand for long-term care institutions occurs due to the care needs, as a result of losses in functional and cognitive capacity, due to the need for a living-place and social contact, due to social inequality, and as a consequence of changes in family arrangements at all socio-economic levels.

Even though most of the population considers the best place for the older adult to live to be with his or her family, the circumstances in which the latter currently finds itself do not provide it with conditions for this to happen, making this a decisive factor in the placing of older adults in long-term care institutions. Thus, it is necessary to think of new modes of inclusion for institutionalized older adults, removing the stigma constructed in defining the condition of old age and being in a care home. ${ }^{6}$

Living in a LTCI continues to be an alternative for those older adults who are unable to live autonomously. ${ }^{7}$ Although studies relating to the issue of the LTCIs continue to report situations of abandonment and isolation, besides the residents' loss of autonomy and identity, ${ }^{7-8}$ there are institutions which, somehow, provide a home and constitute a place for living in comfort while at the same time providing professional care. In this context, moving to live in the institution may be the only possibility for accessing healthcare, social security, and safety, guaranteeing the older adult's quality of life..$^{5-9}$

The LTCIs supply the needs for housing, hygiene, food and monitoring of health, although they tend to remove the older adult from family coexistence. This leads to isolation and physical and mental inactivity, with a consequent reduction in the older adult's quality of life. ${ }^{4}$ In this scenario, the LTCI's multidisciplinary team needs to provide the resident older adults with broader care, encompassing physical, social, psychological, emotional and spiritual aspects. Thus, the inclusion of the families of those older adults who have them, and who make themselves available to participate in the latter's lives, constitute an important tool in the qualification of the care and the quality of life of the institutionalized older adult.

Among the professionals in the LTCI, the nurse has a relevant role in the institutional routine, through performing an administrative, caring and educational role, which contributes to the improvement of the quality of life of the older adult in the institution. ${ }^{10}$ It is understood that the family too, like the older adult, must be a focus of attention of the LTCI's multidisciplinary team. In this scenario, the family can be involved in the planning and undertaking of the care for the institutionalized older adult. ${ }^{11}$

Research in databases regarding the issue involving LTCI revealed that the majority of the investigations address biological aspects of aging, pointing to situations such as isolation and abandonment, as well as institutionalized older adults' loss of identity and autonomy. Studies were not found considering the workers' perception regarding the families of older adults living in a long-term care institution. Hence, undertaking this study is justified by the importance of the issue for nursing, as it is the professionals of this area who provide the care for the population of older adults who live in long-term care institutions.

As a result, this study, in discussing current aspects of the gerontological area, can contribute to the qualification of the care for institutionalized older adults, as - through showing the workers' opinions - it enables these to reflect on their practices, and based on this, to change, if necessary, their way of seeing and working with the older adults' families. In addition, it can produce knowledge that can serve as indicators for nurses and other professionals from the healthcare area. 
In the light of the above, the research question was defined: what is the perception of workers in a LTCI regarding the families of the institutionalized older adults? In order to answer the question, the study aimed to investigate the perception of the workers in a LTCI regarding the families of the institutionalized older adults.

\section{METHOD}

The study was of the exploratory-descriptive type, with a qualitative approach. This design was chosen as it allowed a deeper understanding of the object studied, the perception of workers of a LTCI regarding the older adults' families, with greater flexibility in conducting the study, so as to obtain familiarity with the issue through the interviewees' accounts. ${ }^{12}$

The field research was undertaken in a LTCI with the capacity to attend 210 older adults, located in the Central Region of the State of Rio Grande do Sul. It is made clear that the questions related to sex and issues of gender were not considered in the study. However, in order to maintain consistency with the persons resident in the LTCI and with the accounts of the participants in the study, the residents will be referred to as 'she'. The choice of this scenario is justified as it is a public and philanthropic LTCI, with a multidisciplinary team of 77 workers.

The research subjects were the professionals from the institution's multidisciplinary team. The participants' inclusion met the following criteria: to have been a contracted worker for the LTCI for at least three months; to have a minimum weekly workload of 20 hours; and to have reported contact with the family members of the institutionalized older adults. The sample type was intentional, covering a minimum of one representative from each professional category. The number of participants was defined considering the criteria of saturation in the information set, and when the analysis of the statements met the study's objective. ${ }^{13}$ As a result, the sample's study was made up of 16 workers who worked in the LTCI.

The professional categories which made up the research subjects were: nurse, physiotherapist, physical educator, social worker, nutritionist, pharmacist, psychologist, pedagogue, nursing technician, executive secretary, cook, cleaner, laundry assistant, porter, maintainance technician and driver.
The subjects were invited to participate in the study and were advised regarding the investigation's objective, the voluntary character of participation, and the guarantee of anonymity. The study was based in the legal norms which serve as a basis for studies involving human beings. ${ }^{14}$ The study was approved by the Research Ethics Committee, under Certificate of Presentation for Ethical Consideration n. 0345.0.243.000-11 and process n. 23081.016935/2011-11, in December 2011. The LTCI's management approved the undertaking of the research. All the subjects signed the terms of consent. Data collection occurred between February and June 2012.

The data collection technique was semi-structured interview, with the socio-demographic characterization of the workers. The interview used the following guiding question: how do you perceive the family of the older adult resident in this institution? Based on the participants' answers, further questions were made, with the aim of deepening and elucidating what was produced, allowing flexibility in the conversation and the absorption of new themes and questions raised by the research subjects. The interviews were recorded and transcribed in full, being identified by the letter $\mathrm{W}$ for 'worker' and numbered according to the sequence in which they were undertaken.

Data analysis followed the steps of thematic analysis, ${ }^{12}$ and its operationalization was based in the following steps. Pre-analysis, which consisted of bringing together the material to be analyzed, re-visiting the study's initial objective, with skim reading of the interviews. In the stage of exploration of the material, exhaustive reading of the interviews was undertaken, in order to achieve the text's nucleus of meaning, emphasizing the themes which emerged, these being codified. In the treatment and interpretation of the results obtained, these themes were highlighted, allowing the articulation of the structured material from the interviews and the theoretical framework.

Through following these stages, it was possible, by aggregating the ideas contained in the interviews' content, to construct a category of analysis, termed: the LTCI worker perceiving the family of the institutionalized older adults. Aspects relating to the reduction of visits made by the family to the LTCI, to the occasions when the family goes to the LTCI, to the older adult's abandonment by the family, and to the blood relatives as a reference, are discussed in this category. 


\section{RESULTS}

The study participants were aged between 27 and 62 years old, nine were female and seven male, nine were single, five were married and two were separated. Regarding educational level, four had not finished junior high school; one had finished junior high; two had finished senior high school; one had attended, but not graduated from, higher education; and eight had graduated from university. In relation to religion, 14 stated that they were Roman Catholics, and two, Spiritualists. Monthly income varies between one minimum salary (six participants) and two minimum salaries (10 participants). Regarding how long they had worked in the LTCI, eight participants had worked there for between one and two years; five, for between four and nine years; two, for 13 to 14 years; and one had worked there for 32 years.

\section{The LTCI worker, perceiving the family of the institutionalized older adults}

For the workers, the families came little to the LTCI, so much so that they didn't know who the families were for the majority of the older adults. They frequently experienced the following situation: [...] it is years since the majority came and sometimes we don't know who their families are (W1); few families come, the ones we have as representatives, I see them little here, keeping the older adults company and being with them [...] (W14).

For the participants in the research, the absence or withdrawal of the majority of the families from coexistence with the older adults in the institution seemed to be related to lack of time, as it is common for them not to be present, even on commemorative dates. However, they observed that the older adults wished and hoped for the family's presence. Regarding this situation, they identified loneliness in the older adults. The family is totally distant. You can count those who are present on your fingers. So much so, that on special days, it makes you upset, you know? Because they [the older adults] wait for them, wait for something that isn't coming, you know? (W7); The older adults who still have a relationship with their family, I don't know, whether it is an imposition of their current way of life, but you know, the family members don't have the time which the older adult should have for spending time together. The family members simply have their routine, their life, and they can't manage to be present. So, I perceive that the loneliness prevails in this aspect. The family member cannot manage to come here when the person being assisted needs them most (W10).

There were occasions in which the family came to the LTCI, according to the perception of the workers, on the commemorative dates of Christmas, New Year, Easter, the older adult's birthday and on the occasion of the institution's annual party. The workers perceive that on the weekends, some families would go to the LTCI and, occasionally, the older adults would go to the family members' houses. The families' visits to the older adults in the LTCI occurred according to the family members' availability. The family usually comes to visit on commemorative dates: at Christmas, at Easter, or if they don't come, they take them, they stay for a little while, then they bring them back, but generally it is on these dates (W1); They [the older adults] wait for Christmas for their son to come, because there are children who only come at Christmas, as they live far away. Because, I don't know, if that's what it is, oh! At Christmas it is that family thing, I don't know if the family members think about it more, or whether that is when they can come here (W2); Those more special dates: Christmas, birthday, on the home's party too, the families, it is more on these commemorative dates (W9).

The presence of the family also occurred in situations in which the older adult was weak, ill or dead. In the interviewees' accounts, one can perceive that they felt indignation regarding the family absence, as they reported that the family was present only in situations of illness or when the older adult was dying. When the elderly person is nearly dying and needs to go to hospital, we call the family to care for them, and when the funeral happens the whole family turns up crying desperately for the old person, but they were never able to visit when she was alive (W4); So, I have already seen family members - it is strange to say - but they really come when the old person finally dies. When she was here, alive, nobody came (W14).

The workers referred to abandonment by the family, as they identified situations which brought discomfort to the institutionalized older adults. Abandonment was a very frequent complaint among the older adults, as the families frequently left them in the institution and did not visit them for years. There are families who never appear again, simply left the old person here and never appeared again, total abandonment! (W2); We witness that the older adults who live here don't have this family bond, simply because the family felt they had the right to disconnect from this member (W5); The older adults complain to us about these relatives who abandoned them, because they use this word, that they were abandoned, that they don't come back (W14). 
Illness in the older adults, when associated with the appearance of dependency, creates a need for special care; and in situations such as this, the older adult becomes a problem for some families. In this context, the families prefer to withdraw from the care for the older adult and put him in a LTCI, often abandoning him. The workers perceived that the family thought of the old people's home as a "deposit", as they left the older adult in the institution, not coming back to visit. Many families arrive and say: 'I' $m$ not going to spend the rest of my life caring for an old person' [...] (W2); The older adult who is dependent on care ends up becoming a burden for the family, somebody who is going to need various types of care. So, they [the family members] think of the long-term care institution as a deposit, as something 'where I leave things', and they end up throwing the role which should be theirs in to the lap of the institution (W4).

The workers differentiated those family members who abandoned the older adult from those who were unavailable to appear regularly in the LTCI due to work. The majority of the family members leave the older adults here in the institution and never come back to keep contact. Because for me it is different. I see the issue of leaving a family member in a long-term care institution and the issue of abandoning the family member differently. There are many situations where they [family members] really are working, they have their own children, they have various commitments and they cannot afford the costs of an elderly person who is dependent for various reasons. So they need to place them in a long-term care institution, but that is different from abandoning the family member (W4).

The workers report the older adults' daily wait for some contact from the family, speaking about them and waiting for any news. In this context, they perceive that, for the institutionalized older adults, blood relatives are their reference. I think that the blood relatives are a reference for them [the older adults], as they stay waiting, they have a lot of love, they keep photographs [...] They pass all their time talking about their family, waiting for some letter or a telephone call (W1); I think that the institution tries to do what is possible, but it can't be everything, and I think it never will manage to fill the role of the family. I think that nothing can replace, substitute the role of the family, as it is the reference for the older adults (W4).

The workers identified that, for the older adults, the family might not be ideal, but was, nevertheless, family. Despite the family's staying away from the older adult for months or years, when it was present, the feeling of abandonment reduced. The older adults might have various negative feelings in relation to their families, but they considered them important. There is one granny whose family telephones, and when the telephone rings, she pounces on it, and after she puts it down, she says: 'my rich son rang me!' I think they give more importance to their families than their families give to them. Unfortunately that is the impression that I have (W1); One thing that the older adults say is that the family might be the worst ever, but it is still family. So, for them, no matter how lame the family is, even if it comes just once a year, when it comes, it makes up for the whole year that it was away, that it was distant (W14).

The workers perceived that the family's participation had positive effects on the older adults' health; when it was present, they became more happy and collaborative. They mentioned that often, what was missing in the LTCI for meeting the older adults' comprehensive needs was the presence and the reference provided by the family. You try to make the old ladies happier. You try to take them on outings. There are many who don't like going, who get depressed and close up. What the old people really want is their family. When the family is here, they are better, you know? The old ladies' emotional state is better and we can manage to work more with them (W2); I always say the following to the family members: look, we provide the healthcare for the elderly person, but nobody can substitute family bonds (W5); The older adults' contact with the family is very important, actually, it is what is missing for them. Because here, the older adults are well cared for, they have the care possible, but this issue of the family, which is the most important thing for everybody, they miss it a lot (W9).

\section{DISCUSSION}

The LTCI workers' perception regarding the institutionalized older adults' families, in this study, indicates a context of distinct behaviors among the family members. Families which were present very little or which, were even absent were evidenced, as were those which were attentive and maintained a bond with the older adults. The literature shows this ambivalence regarding the relationships between the institutionalized older adults and their families. A study undertaken with older adults resident in three old people's homes identified that $67 \%$ of the institutions' older adults received visits from their family members. Specifically, in two of the institutions, $62 \%$ of the older adults reported that they would not like to 
be living with their family, while $58 \%$ of the older adults from the other institution manifested the wish to live with the family members. ${ }^{15}$ Another study ${ }^{16}$ observes that the majority of institutionalized older adults have rare contacts with their family members, and that some do not have family. Thus, the studies indicate different positions of the family regarding visiting the institutionalized older adults. These studies' results validate the perception of the workers in the LTCI investigated.

It is observed that following institutionalization, the older adult's support network becomes poor and weakened. ${ }^{17}$ This denotes that, often, the older adults' institutionalization entails the reduction of family bonds, which were perhaps already few or nearly non-existent.

The workers in the present study perceived the older adults' institutionalization as often being the family's only option; as a consequence, they perceive that the family did not feel responsible for the older adults. In this scenario, it is relevant to understand the circumstances which contributed to this situation, assessing the family's strengths and weaknesses, as this broadens knowledge of the same, ${ }^{18}$ and, based on this, to propose a plan of intervention so as to seek the approximation of the family of the institutionalized older adult. As the time spent in the old peoples' home passes, the family bonds weaken, accompanied by the scarcity of contact and family losses. ${ }^{19}$

In the institution in question, the workers perceived that some families made more visits on special dates and commemorative occasions. These occasions encourage the presence of the family due to the festive and relaxed atmosphere. The care institutions tend, as a result, to commemorate these in order to promote approximation between the older adults and their family members. ${ }^{11}$

When the older adult resident in the institution becomes ill, the workers in this study communicate to the family that it should visit. In the situations in which the family does not attend the institution, the professionals develop negative feelings in relation to it. This becomes more intense when the family appears at the institution only upon the death of the older adult. These experiences influence how the workers understand the institutionalized older adults' families. Hence, starting from the assumption that the families were little interested in the older adults, the workers tended to consider that this was the predominant behavior and, thus, did not create settings which favored the approximation of the family with the institution and as a consequence, with the elderly person.

Another aspect which emerged in the results relates to the situation of abandonment of the elderly adult by the family. Experiencing old age in an old people's home, without having the family present, leads the elderly person to a constant condition of waiting for something or somebody. ${ }^{20} \mathrm{As}$ a result, a constant concern of these professionals is to motivate the family members to participate actively in the care for the older adult, establishing a bond between the elderly person, the family, and the professional. ${ }^{21}$

In the view of the workers, some families saw the LTCI as a "deposit", where they could leave the older adult and exempt themselves from the responsibility. This result supports a study undertaken with institutionalized older adults in which the institution was identified as a "deposit for old people". These older adults live, most of the time, with limited possibilities for an affective, social or sexual life. ${ }^{22}$

In the understanding of this study's participants, abandonment differs depending on whether it is because the family does not have the conditions for taking responsibility for the care of the older adult, or whether it is because they are not interested in taking responsibility for this care. Abandonment by the family is provoked by circumstances relating to the weakness, the breaking, or the absence of the affective and social relationships of the family with the institutionalized older adults, characterized by the older adults' feelings of suffering. These results reflect that the institutionalized older adult is no longer part of the relationships with the family and friends among whom the trajectory of her life was constructed. ${ }^{19}$

The older adult's relationships with her close relatives were generally important, as these were the persons with whom she wished to maintain links. Even though the family members were physically distant from the institutionalized older adults, blood relatives were considered the reference, principally regarding emotional support and protection. The support is facilitated when the links of loyalty are cultivated in spite of geographical distance. ${ }^{23}$ In addition, the institutionalized older adults, their family members and the caregivers of the long-term care institutions must construct a partnership and define common objectives, so as to - among other aspects - improve performance of self-care of those older adults who need long-term care. ${ }^{24}$ 
In this study, it was perceived that the workers valued the presence of the family in the LTCI. However, with the structural changes which have been occurring with families, they have found difficulties in performing the tasks which commonly used to be attributed to them. One should not blame the family for this, but, rather, offer conditions, resources and alternatives such that it can accompany and care for its elderly members. ${ }^{4}$ In this regard, one study undertaken identified that the family could be the key element for the qualification of the care in the LTCI, especially in relation to the direct care for the older adult. ${ }^{11}$ The maintenance of the bond between the family and the institutionalized older adult is significant, as it is a competence of the family to provide protection, affection and emotional support, as well as to preserve the family bonds, which promotes the care and the socialization of the older adult.

\section{FINAL CONSIDERATIONS}

In seeking to investigate the perception of the workers of the LTCI regarding the institutionalized older adults' families, it is identified that they perceive that the older adults' contact with their families, in the context studied, was, on most occasions, reduced, due to the family visiting the institution little. The commemorative dates were the principal occasions on which the family made itself present. However, they evidenced some situations of abandonment, in which the family did not visit the older adult, even when called.

The workers differentiated the family's abandoning the older adult from the family not having the conditions to take responsibility for her care. In their view, the family does not always have the conditions or find itself prepared to care for the older adult, and the LTCI constitutes an alternative for care of older adults, taking responsibility for them. For the workers, the strengthening and maintenance of the family's bonds, responsibility and emotional support can be an element which minimizes the older adults' feeling of abandonment. This form of thinking is based on the conception that nobody can take the place of the blood relatives, as these are the reference for the older adults. In this sense, spending time with the family is one of the older adults' needs. This is because, no matter how efficient the institution may be, or how competent and warm the staff may be, they cannot substitute the role of the older adults' family in the psycho-emotional aspect or in the aspect of belonging to a family unit.
In summary, emphasis is placed on the importance of undertaking further studies, in which the scenarios should be LTCIs with social and cultural contexts which are different from that investigated, so as to broaden and compare the results found, as well as to indicate divergences and points in agreement based on multiple views regarding the families of institutionalized older adults.

Based on this study's results, integration and experience between the family and the institutionalized older adults is recommended, respecting the different understandings of the intrafamily relationship in the context present, such that the older adult/family bond may be enriched.

\section{REFERENCES}

1. Marinho LM, Vieira MA, Costa SM, Andrade JMO. Grau de dependência de idosos residentes em instituições de longa permanência. Rev Gaúcha Enferm. 2013 Fev; 34(1):104-10.

2. Jerez-Roig J, Souza DLB, Lima KC. Incontinência urinária em idosos institucionalizados no Brasil: uma revisão integrativa. Rev Bras Geriatr Gerontol. 2013 Ago; 16(4):865-79.

3. Camarano AA. Instituições de longa permanência e outras modalidades de arranjos domiciliares para idosos. In: Neri AL, organizador. Idosos no Brasil: vivências, desafios e expectativas na terceira idade. São Paulo (SP): Fundação Perseu Abramo; 2007. p.169-90.

4. Pollo SHL, Assis M. Instituições de Longa Permanência para Idosos - ILPIS: desafios e alternativas no município do Rio de Janeiro. Rev Bras Geriatr Gerontol [online]. 2008 [acesso 2014 Abr 08]; 11(1):29-44. Disponível em: http:// revista.unati.uerj.br/scielo.php?script $=\mathrm{sci}_{-}$ arttext\&pid=S1809-982320080001000 04\&lng=pt

5. Camarano AA, Kanso S. As instituições de longa permanência para idosos no Brasil. R Bras Est Pop. 2010 Jan-Jun; 27(1):233-5.

6. Costa MCNS, Mercadante EF. O idoso residente em ILPI (Instituição de Longa Permanência do Idoso) e o que isso representa para o sujeito idoso. Rev Kairós Gerontol. 2013 Mar; 16(2):209-22.

7. Bessa MEP, Silva MJ. Motivações para o ingresso dos idosos em instituições de longa permanência e processos adaptativos: um estudo de caso. Texto Contexto Enferm. 2008 Abr-Jun; 17(2):258-65.

8. Lenardt MH, Michel, T, Tallmann, AEC. A condição de saúde de idosas residentes em uma instituição de longa permanência. Cogitare Enferm. 2009 Abr-Jun; 14(2):227-36.

9. Gamburgo LJ, Monteiro MI. Singularidades do envelhecimento: reflexões com base em conversas com um idoso institucionalizado. Interface Comunic Saúde Educ. 2009 Jan-Mar; 13(28):31-41. 
10. Santos SS, Silva BT, Barlem EL, Lopes RS. O papel do enfermeiro na instituição de longa permanência para idosos. Rev Enferm UFPE [online]. 2008 [acesso 2013 Set 11] Jul-Set; 2(3):291-9. Disponível em: http:// www.revista.ufpe.br/revistaenfermagem/index. $\mathrm{php} /$ revista/article/view/351/pdf_386

11. Creutzberg M, Gonçalves LHT, Sobottka EA, Santos BRL. A comunicação entre a família e a instituição de longa permanência para idosos. Rev Bras Geriatr Gerontol. 2007 Ago; 10(2):147-6.

12. Minayo MCS. O desafio do conhecimento: pesquisa qualitativa em saúde. $12^{\mathrm{a}}$ ed. São Paulo (SP): Hucitec; 2010.

13. Fontanella BJ, Ricas J, Turato ER. Amostragem por saturação em pesquisas qualitativas em saúde: contribuições teóricas. Cad Saúde Pública. 2008 Jan; 24(1):17-27.

14. Ministério da Saúde (BR), Conselho Nacional de Saúde. Resolução n. 196, de 10 de outubro de 1996: diretrizes e normas regulamentadoras de pesquisa envolvendo seres humanos. Brasília (DF); 1996.

15. Davim RMB, Torres GV, Dantas SMM, Lima VM. Estudo com idosos de instituições asilares no município de Natal (RN): características socioeconômicas e de saúde. Rev Latino-Am Enferm. 2004 Mai-Jun; 12(3):518-24.

16. Polaro SHI, Fideralino JCT, Nunes PAO, Feitosa ESF, Gonçalves LHT. Idosos residentes em instituições de longa permanência para idosos da região metropolitana de Belém-PA. Rev Bras Geriatr
Gerontol. 2012 Set; 15(4):777-84.

17. Rodrigues AG, Silva AA. A rede social e os tipos de apoio recebidos por idosos institucionalizados. Rev Bras Geriatr Gerontol. 2013 Dez; 16(1):159-70.

18. Rissardo LK, Furlan, MCR, Grandizolli G, Marcon SS, Carreira L. Concepção e sentimentos de idosos institucionalizados sobre família. Cienc Cuid Saude. 2011; 10(4):682-9.

19. Alves-Silva JD, Scorsolini-Comin F, Santos MA. Idosos em instituições de longa permanência: desenvolvimento, condições de vida e saúde. Psicol: Reflex Crít. 2013 Jun; 26(4):820-30.

20. Freitas AVS, Noronha CV. Elderly people in longterm institutions: speaking about care. Interface Comunic Saude Educ. 2010 Abr-Jun; 14(33):359-69.

21. Piexak DR, Freitas PH, Backes DS, Moreschi C, Ferreira CLL, Souza MHT. Percepção de profissionais de saúde em relação ao cuidado a pessoas idosas institucionalizadas. Rev Bras Geriatr Gerontol. 2012; 15(2):201-8.

22. Pavan FJ, Meneghel SN, Junges JR. Mulheres idosas enfrentando a institucionalização. Cad Saúde Publica. 2008 Set; 24(9):2187-9.

23. Wright LM, Leahey M. Enfermeiras e famílias: um guia para avaliação e intervenção na família. $5^{\mathrm{a}} \mathrm{ed}$. São Paulo (SP): Roca; 2012.

24. Chang SH, Yu CL. Perspective of family caregivers on self-care independence among older people living in long-term care facilities: A qualitative study. Int J Nurs Stud. 2013; 50: 657-663. 